\title{
A molecular phylogeny of wood-borers (Teredinidae) from Japanese Tsunami Marine Debris
}

\author{
Nancy C. Treneman ${ }^{1, *}$, Luisa M.S. Borges ${ }^{2}$, J. Reuben Shipway ${ }^{3}$, Michael J. Raupach $^{4,5}$, Bjørn Altermark ${ }^{6}$ \\ and James T. Carlton ${ }^{7}$ \\ ${ }^{1}$ Oregon Institute of Marine Biology, PO Box 5389, Charleston, OR, 97420 USA \\ ${ }^{2}$ Scientific Solutions, Runder Berg 7a, 21502 Geesthacht, Germany \\ ${ }^{3}$ Ocean Genomic Legacy Center, Northeastern University, Marine Sciences Center, 430 Nahant Road, Nahant, MA, 01908 USA \\ ${ }^{4}$ Senckenberg am Meer, Deutsches Zentrum für Marine Biodiversitätsforschung, AG Molekulare Taxonomie mariner Organismen, \\ Südstrand 44, 26382 Wilhelmshaven, Germany \\ ${ }^{5}$ Institute for Biology and Environmental Sciences, Carl von Ossietzky University, Oldenburg, Carl von Ossietzky Str. 9-11, 26111 \\ Oldenburg, Germany \\ ${ }^{6}$ Department of Chemistry, Faculty of Science and Technology, UiT- The Arctic, University of Norway, PB 6050 Langnes, 9037 \\ Tromsø, Norway \\ ${ }^{7}$ Maritime Studies Program, Williams College-Mystic Seaport, Mystic, CT, 06355 USA \\ Authore-mails: ntreneman@gmail.com (NCT),luisaborges2000@yahoo.co.uk(LMSB),reuben.shipway@gmail.com(JRS), \\ michael.raupach@rub.de(MJR),bjorn.altermark@uit.no(BA),james.t.carlton@williams.edu (JTC) \\ *Corresponding author
}

Received: 16 March 2017 / Accepted: 6 November 2017 / Published online: 20 February 2018

Handling editor: Amy Fowler

\section{Co-Editors' Note:}

This is one of the papers from the special issue of Aquatic Invasions on "Transoceanic Dispersal of Marine Life from Japan to North America and the Hawaiian Islands as a Result of the Japanese Earthquake and Tsunami of 2011." The special issue was supported by funding provided by the Ministry of the Environment (MOE) of the Government of Japan through the North Pacific Marine Science Organization (PICES).

\begin{abstract}
The family Teredinidae (shipworms) contains 70-plus species of boring bivalves specialized to live in and digest wood. Traditional means of species identification and taxonomy of this group encounter numerous challenges, often compounded by the diverse and dynamic nature of shipworm ecology and distribution. Modern integrative taxonomic methods are shedding new light on this complex group, from delineating cryptic species to resolving phylogenetic relationships within the family. This study reported new sequence data from shipworm species rafted from the western to eastern Pacific Ocean in woody marine debris resulting from the Japanese tsunami of 2011. Eight species of shipworms were found in this debris and tissue from five species was collected. Partial nuclear ribosomal 18S rRNA gene sequences were obtained from Bankia bipennata (Turton, 1819), Bankia carinata (Gray, 1827), Psiloteredo sp., Teredora princesae (Sivickis, 1928), and Teredothyra smithi (Bartsch, 1927). A 658 base pair fragment of COI was successfully sequenced from Psiloteredo sp. and T. princesae specimens from tsunami debris, as well as Psiloteredo megotara (Hanley, 1848) from Europe and Nototeredo norvagica (Spangler, 1792) from Scandinavia. Psiloteredo sp. is very similar morphologically to the North Atlantic Ocean P. megotara; however, these two species are genetically distinct with a $12.8 \%$ K2P distance in their COI sequences. The transport of shipworms across the North Pacific Ocean in woody debris generated by a tsunami shows that major geologic events can connect previously isolated geographic areas and provide the opportunity for the establishment of invasive species and subsequent speciation.
\end{abstract}

Key words: phylogeny, Teredinidae, shipworms, tsunami, Pacific Ocean 


\section{Introduction}

The Teredinidae, commonly called shipworms, are a specialized group of bivalves that primarily bore into and digest wood. The 70-plus species (Turner 1966, 1971; Voight 2015), all but a few of which are marine, are found in driftwood, timbers, wooden vessels, pilings and dikes, and seagrass rhizomes (Turner 1966; Distel et al. 2003; Shipway et al. 2016). The valves of the Teredinidae are reduced in size and are used by the animal for boring. The long, fragile body is encased in a bored tunnel lined with calcium carbonate secreted by the shipworm's mantle. Pallets, unique to the family, are paired calcareous structures on either side of the siphons and are used to seal the burrow, thereby protecting the animal from predation and desiccation.

Shipworms are challenging taxonomically due to the degree of morphological variation in their shells within and between species. The pallets have a more specific morphology between species than the shells, and are therefore used as the primary characteristic for species identification, although intraspecific variation (Figure 1) also can be considerable (Turner 1966; MacIntosh 2012; Borges 2015). Moreover, for some teredinid species groups, the differences between pallets are subtle and difficult to discern (Calloway and Turner 1987; Borges 2015). In addition, pallets and shell morphology may be affected by environmental factors such as population density within a wood item, wood type, and ocean conditions (Turner 1966).

Shipworm density may be limited by available wood volume and the number of individuals competing for space and food (MacIntosh et al. 2012, 2014). Wood is the primary nutritional source for most shipworms except for a few species that bore into seagrass rhizomes, mud, and rock (Turner 1966; Lozouet and Plaziet 2008; Distel et al. 2011). Due to the ephemeral nature of their habitat, which is destroyed as they grow, shipworms are quick to reach sexual maturity-many within five to six weeks of larval settlement on wood (Turner and Johnson 1971; Calloway and Turner 1988). Approximately a third of the species brood larvae within their gills; the rest are broadcast spawners. Two brooding strategies are found in shipworms: short term brooders, which retain larvae until the straight hinge stage; and long term brooders, which release pediveliger larvae immediately ready to settle on wood (Turner and Johnson 1971; Calloway and Turner 1988).

Species of nearshore and coastal shipworms disperse through rafting in driftwood and currentmediated transport of larvae (Edmondson 1962;
Thiel and Haye 2006; Shipway et al. 2014). Depending on the species, the larvae of broadcasters have between 3 and 6 weeks, those of short term brooders from 2 to 4 weeks, and those of long term brooders from 1 to 2 weeks to settle on wood (Calloway and Turner 1988). The advent of maritime trade and travel in wooden vessels provided an avenue for the worldwide dispersal of many species (Turner 1966; Carlton 1999; Carlton and Eldredge 2009). The transition from wood to iron ocean-going vessels reduced the anthropogenic transport of adults (Nelson 2016); however, ballast water, taken up at one location and released in another, may continue to distribute shipworm larvae to geographically disjunct areas (Carlton 1987; Carlton 1999; Shipway et al. 2014). The natural ranges and origins of some species have thus become obscured over the centuries (Turner 1966; Carlton 2009).

Cryptic species, morphologically identical but genetically distinct, have been discovered to have different geographic distributions (Borges et al. 2012), and yet the amphi-Atlantic population of the shipworm Teredo navalis (Linnaeus, 1758), a cosmopolitan species, shares the same haplotypes throughout the northern Atlantic basin (Weigelt et al. 2016). The comparison of DNA sequences within and between species in these studies and others has produced valuable insights into shipworm population structure, geographic origins, species delineation, and phylogenetic relationships (Distel et al. 2011; Borges et al. 2012; Shipway et al. 2016; Weigelt et al. 2016).

DNA sequences from species from a wide range of taxa and geographic localities are needed for a robust molecular analysis of any taxonomic group. Publicly accessible genetic databases such as NCBI (National Center for Biotechnology Information) and the Barcode of Life Database (BOLD) (Ratnasingham and Hebert 2007) contain few shipworm sequences, and very few from the North Pacific Ocean. Wood debris from the 2011 Japanese tsunami (Japanese Tsunami Marine Debris, JTMD) that traversed and circulated in the northern Pacific began arriving on Hawaiian and eastern Pacific beaches in 2012 (Maximenko et al. 2015; Carlton et al. 2017). Eight species of shipworm were found in this woody tsunami debris: Bankia bipennata (Turton, 1819), Bankia carinata (Gray, 1827), Teredothyra smithi (Bartsch, 1927), Psiloteredo sp., Lyrodus takanoshimensis (Roch, 1929), Teredo navalis Linnaeus, 1758, Teredora princesae (Sivickis, 1928) and Uperotus clava (Gmelin, 1791) (Treneman et al. 2018). The first 6 species listed are resident in Japanese coastal waters (Tsunoda 1979; Haga 2017). T. princesae and $U$. clava are pelagic species usually found in driftwood and floating seeds (Edmondson 1962; Rayner 


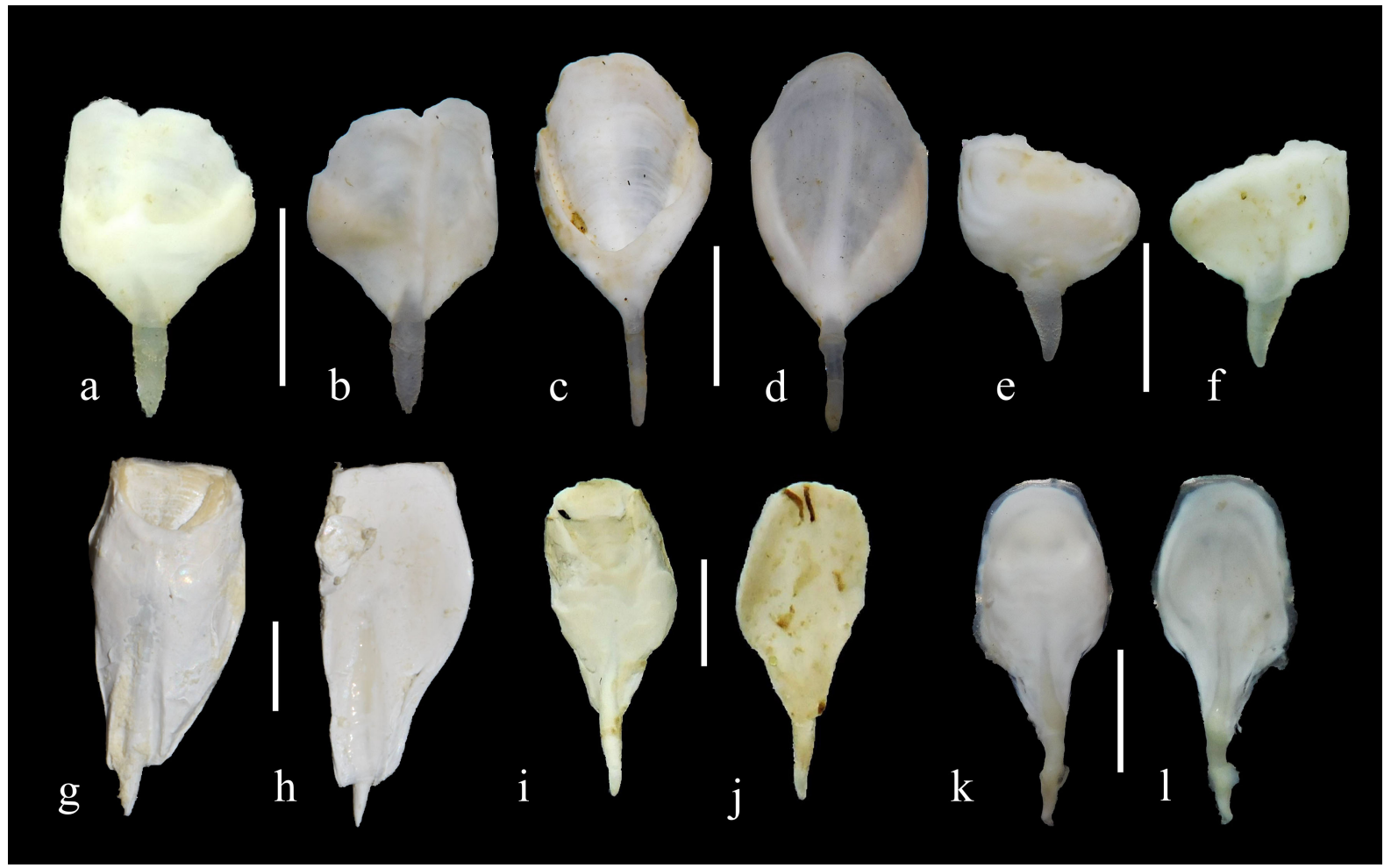

Figure 1. (a-f) Intraspecific variation in the pallets of Teredora princesae, scale bars $4 \mathrm{~mm}$. (a, b) Outer and inner face, respectively, of pallet from JTMD construction beam stranded on Long Beach, Washington, USA. (c, d) Inner and outer face, respectively, of pallet from JTMD construction beam stranded on Kauai, Hawai'i. (e, f) Pallet from same item as a, b (e) outer face (f) inner face. (g-1) Scale bars 2 mm. $(\mathrm{g}, \mathrm{h})$ Outer and inner, face, respectively, of Psiloteredo megotara pallets from Tromsø, Norway. (i, j) Outer and inner face, respectively, of Psiloteredo sp. pallet from JTMD post-and-beam wood washed ashore at Newport, Oregon. (k, l) Outer and inner face, respectively of Psiloteredo sp. pallet (provided by T. Haga) from a 290 meter depth off the northeast coast of Honshu, Japan (all photos by NC Treneman).

1983). Tissue from multiple species of living shipworms was recovered from seven items. Partial DNA sequences for the $18 \mathrm{~S}$ ribosomal nuclear gene were obtained for five of these species and a fragment of the mitochondrial cytochrome $c$ oxidase subunit 1 gene (COI) was sequenced for two of these species.

Insights gained on shipworm evolution, dispersal, and species delineation through the analysis of these sequences were the object of this study.

\section{Materials and methods}

Field surveys, identification, and preservation of specimens from Japanese Tsunami Marine Debris (JTMD)

Beach surveys were conducted from 2013 to 2017 along the British Columbia, Washington, and Oregon coasts $\left(38^{\circ} \mathrm{N}\right.$ to $\left.50^{\circ} \mathrm{N}\right)$, and in Hawai' $\mathrm{i}$ on Oah' $\mathrm{u}$ and Kauai $\left(21.3^{\circ}\right.$ to $\left.22.1^{\circ} \mathrm{N}\right)$. Identification of JTMD wooden "post-and-beams" was possible due to their mortise and tenon carpentry, unique when compared to locally processed wood (Treneman et al. 2018). Of the 82 JTMD wood items examined, seven yielded living specimens (Table 1). Tissue and whole specimens of five species, all broadcast spawners, were recovered: Bankia bipennata, Bankia carinata, Psiloteredo sp., Teredora princesae, and Teredothyra smithi. Only pallets and shells of Uperotus clava and the two brooding species, Lyrodus takanoshimensis and Teredo navalis were recovered.

Upon extraction from the wood, specimens were examined for identification and anatomical measurements and preserved in 95\% ethanol. Each specimen was imaged and ancillary data were collected. Pallets were used for species identification according to Turner $(1966,1971)$. Specimens were compared with material at the Museum of Comparative Zoology (MCZ) Harvard University, (Cambridge, Massachusetts) and the Bernice Pauahi Bishop Museum (BPBM) (in Honolulu, Hawaii). Independent identifications were made by the authors from photographs and in-hand examination. For the full methodology see Treneman et al. (2018). Vouchers for 
Table 1. Species, number of specimens collected and sampling location and GenBank accession numbers of all the sequences used in the analysis. BF numbers are JTMD registry (Carlton et al. 2017) numbers of the individual wood JTMD items the specimens were collected from. Sequence Source: 1 - Ocean Genome Legacy Center at Northeastern University Marine Sciences Center, Nahant MA, USA; 2 - Institute of Chemistry, University of Tromsø, Norway; 3 - German Centre for Marine Biodiversity Research at Senckenberg am Meer, Wilhelmshaven, Germany.

\begin{tabular}{|c|c|c|c|c|}
\hline \multirow{2}{*}{$\begin{array}{l}\text { Species } \\
\text { (no. of specimens) }\end{array}$} & \multirow{2}{*}{$\begin{array}{l}\text { JTMD Sample or Specimen } \\
\text { Source, and Specimen Number } \\
\text { (this study only) }\end{array}$} & \multicolumn{2}{|c|}{ GenBank accession numbers } & \multirow{2}{*}{ Reference } \\
\hline & & COI-5P & $18 \mathrm{~S}$ & \\
\hline Bankia bipennata (1) & JTMD BF 171: Specimen No. 27 & & KY250360 & This study $^{1}$ \\
\hline Bankia carinata (1) & JTMD BF 171: 28 & & KY250355 & This study $^{1}$ \\
\hline Bankia carinata (2) & Mersin, Turkey & KC157914; KC157934 & KC158195; KC158213 & Borges et al. 2012 \\
\hline Bankia carinata (1) & Bonaire & & JF899203 & Distel et al. 2011 \\
\hline Bankia carinata $(1)$ & Tobago & & AF120625 & $\begin{array}{c}\text { Giribet and } \\
\text { Wheeler } 2002\end{array}$ \\
\hline Lyrodus pedicellatus (2) & Brittany, France & KC157917; KC157918 & KC158198; KC158199 & Borges et al. 2012 \\
\hline Lyrodus pedicellatus (1) & Portsmouth, UK & & AM774540 & Taylor et al. 2007 \\
\hline Lyrodus pedicellatus (2) & Mersin, Turkey & KC157916; KC157932 & KC158197; KC158211 & Borges et al. 2012 \\
\hline Nototeredo norvagica (2) & Brittany, France & KC157924; KC157925 & KC158205; KC158206 & Borges et al. 2012 \\
\hline Nototeredo norvagica (2) & Mersin, Turkey & KC157926; KC157927 & KC158207; KC158208 & Borges et al. 2012 \\
\hline Nototeredo norvagica (2) & Kaș, Turkey & KC157923; KC157933 & & Borges et al. 2012 \\
\hline Nototeredo norvagica (3) & Strømstad, Sweden & KY274182-KY274184 & & This study ${ }^{1}$ \\
\hline Pecten jacobaeus (1) & Ankara, Turkey & JQ623969 & & GenBank \\
\hline Pholas dactylus (1) & Charmouth, UK & & JF899220 & Distel et al. 2011 \\
\hline Psiloteredo megotara (2) & Tromsø, Norway: PMN1, 3 & KY274185; KY274187 & KY250340; KY250342 & This study $^{2}$ \\
\hline Psiloteredo megotara (1) & $\begin{array}{l}\text { Longyearbyen, Svalbard, } \\
\text { Norway: PMN2 }\end{array}$ & & KY250341 & This study $^{2}$ \\
\hline Psiloteredo megotara (5) & Strømstad, Sweden: PMNS1-5 & KY274186 & KY250335-KY250339 & This study $^{1}$ \\
\hline Psiloteredo sp. (7) & $\begin{array}{l}\text { JTMD BF 128: } 1,4,9 ; \text { BF } 165: \\
2,3,6,7\end{array}$ & & KY250343-KY250349 & This study $^{1}$ \\
\hline Psiloteredo sp. (6) & $\begin{array}{l}\text { JTMD BF 128: 1,10; BF 165: } \\
2,3,8 ; \text { BF 171: } 5\end{array}$ & KY250324-KY250329 & & This study $^{3}$ \\
\hline Teredora princesae (5) & $\begin{array}{l}\text { JTMD BF 171: 12,15,18,19; } \\
\text { BF128: } 13\end{array}$ & & KY250350-KY250354 & This study $^{1}$ \\
\hline Teredora princesae (5) & $\begin{array}{l}\text { JTMD BF171: 12,14,18,19; } \\
\text { BF128: } 13\end{array}$ & KY250330-KY250334 & & This study $^{3}$ \\
\hline Teredora sp. (1) & Massachusetts, USA & & KY250356 & This study $^{1}$ \\
\hline Teredothyra smithi (3) & JTMD BF 128: 25,26; BF 171: 23 & & KY250357-KY250359 & This study ${ }^{1}$ \\
\hline Teredothyra dominicensis (2) & Antalya, Turkey & KC157940; KC157941 & KC158219; KC158220 & Borges et al. 2012 \\
\hline Teredothyra dominicensis (1) & Bonaire & & JF899225 & Distel et al. 2011 \\
\hline
\end{tabular}

specimens and DNA will be deposited at the Ocean Genome Legacy (OGL).

\section{DNA extraction, PCR and sequencing}

DNA barcode sequences were obtained in three laboratories. All JTMD COI sequencing was done at the Deutsches Zentrum für Marine Biodiversitätsforschung (DZMB) (German Center for Marine Biodiversity Research) at Senckenberg am Meer, Wilhelmshaven, Germany. The COI sequences of specimens of Psiloteredo megotara (Hanley, 1848) from Norway and Sweden were sequenced at the Institute of Chemistry, University of Tromsø, Norway and at Ocean Genome Legacy Centre at Northeastern
University Marine Sciences Center, Nahant, USA, respectively. The latter two laboratories also sequenced the partial 18S rRNA gene sequences used in this study (Table 1).

At the DZMB the sequences were generated by extracting the total genomic DNA from tissue samples using the NucleoSpin ${ }^{\circledR}$ Tissue Kit (MachereyNagel, Düren, Germany), and following the extraction protocol. Polymerase chain reaction (PCR) was performed for the amplification COI barcode fragment using the primer pair LCO1490 and HCO2198 (Folmer et al. 1994). All PCR products were amplified using illustraTM puReTaq Ready-To-Go PCR Beads (GE Healthcare, Buckinghamshire, UK) in a total volume of $20 \mu \mathrm{L}$, containing $17.5 \mu \mathrm{L}$ sterile molecular 
grade $\mathrm{H}_{2} \mathrm{O}, 2 \mu \mathrm{L}$ DNA template with an DNA amount between 50 to $150 \mathrm{ng} / \mu \mathrm{L}$ and $0.25 \mu \mathrm{L}$ of each primer $(20 \mathrm{pmol} / \mu \mathrm{L})$. The PCR thermal conditions included an initial denaturation at $94{ }^{\circ} \mathrm{C}(5 \mathrm{~min})$, followed by 38 cycles at $94{ }^{\circ} \mathrm{C}$ (denaturation, $45 \mathrm{~s}$ ), $48^{\circ} \mathrm{C}$ (annealing, $45 \mathrm{~s}), 72^{\circ} \mathrm{C}$ (extension, $80 \mathrm{~s}$ ), and a final extension step at $72{ }^{\circ} \mathrm{C}(7 \mathrm{~min})$. All PCR amplification reactions were conducted using an Eppendorf Mastercycler ${ }^{\circ}$ Pro system (Eppendorf, Hamburg, Germany). Negative and positive controls were included with each round of reactions. Two $\mu \mathrm{L}$ of the amplified products were verified for size conformity by electrophoresis in a $1 \%$ agarose gel with GelRedTM using commercial DNA size standards, whereas the remaining PCR product was purified with the NucleoSpin ${ }^{\circledR}$ Gel and PCR Clean-up Kit (Macherey-Nagel, Düren, Germany). Purified PCR products were cycle sequenced and sequenced in both directions at a contract sequencing facility (GATC, Konstanz, Germany) using the primer sequences as matrix. Double stranded sequences were assembled with the Geneious version 7.1.5 program package (Biomatters, Auckland, New Zealand). BLAST searches were performed to confirm the identity of all new sequences (Zhang et al. 2000, Morgulis et al. 2008).

At Tromsø University, genomic DNA was isolated from $30 \mathrm{mg}$ siphon tissue of Psiloteredo megotara following the method described in Meeker et al. (2007). The tissue was washed three times by vortexing in milliQ water. $\mathrm{NaOH}(100 \mu \mathrm{l}, 50 \mathrm{mM})$ together with a 10 min incubation time at $95{ }^{\circ} \mathrm{C}$ was used. A 659 bp fragment of COI was amplified using the PCR primer pair LCO1490 and HCO2198 (Folmer et al. 1994). Template DNA $(3 \mu \mathrm{l})$ and 1.25 units of Taq DNA polymerase were used in a $50 \mu \mathrm{l}$ standard reaction setup. The reaction was denatured at $94{ }^{\circ} \mathrm{C}$ for $1 \mathrm{~min}$ and subjected to 5 cycles of $30 \mathrm{~s}$ at $94^{\circ} \mathrm{C}$, $1.5 \mathrm{~min}$ at $45^{\circ} \mathrm{C}$ and $1 \mathrm{~min}$ at $72{ }^{\circ} \mathrm{C}$, then 35 cycles of $30 \mathrm{~s}$ at $94{ }^{\circ} \mathrm{C}, 1.5 \mathrm{~min}$ at $51^{\circ} \mathrm{C}$ and $1 \mathrm{~min}$ at $72{ }^{\circ} \mathrm{C}$ with a final extension step at $72{ }^{\circ} \mathrm{C}$ for five minutes. A $\sim 1800$ bp fragment of the 18S rRNA gene was amplified using the primer pair ss5 and ss3 (Rowan and Powers 1992). Reaction setup was as for the COI fragment. The reaction was denatured at $94{ }^{\circ} \mathrm{C}$ for 1 min and subjected to 30 cycles of $30 \mathrm{~s}$ at $94^{\circ} \mathrm{C}, 30 \mathrm{~s}$ at $55{ }^{\circ} \mathrm{C}$ and 2 min at $72{ }^{\circ} \mathrm{C}$ with a final extension step at $72{ }^{\circ} \mathrm{C}$ for five minutes. Amplification products were purified using ExoSap IT (Affymetrix). Sequencing PCR was performed using the same primers and according to standard procedures using Big Dye Terminator 3.1 Cycle Sequencing Kit (Life Technologies). The samples were run on an ABI PRISM 3700 genetic analyzer (Applied Biosystems) at the University of Tromsø core facility for DNA sequencing.
All specimens at the Ocean Genome Legacy Center were preserved in absolute ethanol and stored at $-20{ }^{\circ} \mathrm{C}$ prior to DNA extraction. Total genomic DNA was extracted from siphonal tissue and associated musculature using the DNeasy blood \& tissue kit (Qiagen), following the manufacturer's protocol. The approximate concentration, purity and yield of DNA were determined by UV spectrophotometry (Nanodrop 1000, ThermoFisher Scientific, Waltham, MA). Both fragments of the mitochondrial cytochrome $c$ oxidase subunit I (COI) and the nuclear 18S rRNA gene were amplified from the resultant DNA preparations by PCR. Amplification reactions were prepared using $12.5 \mu \mathrm{L}$ of high fidelity polymerase solution (OneTaq ${ }^{\circledR}$, New England Biolabs, Ipswich, Massachusetts), $0.5 \mu \mathrm{L}$ of each primer $(10 \mathrm{mM}), 1-2 \mu \mathrm{L}$ DNA template $(10-20 \mathrm{ng} / \mu \mathrm{L})$, filled up to a total volume of $25 \mu \mathrm{L}$ with molecular grade water.

The COI-5P region was amplified using the primer pair LCO1490 and HCO2198 (Folmer et al. 1994). A small fragment of the 18S rRNA gene was amplified using the primer pair SSU_FO4 and SSU_R22 (Blaxter et al. 1998). The PCR protocol for the COI gene was as follows: an initial denaturation step of $94{ }^{\circ} \mathrm{C}$ for $30 \mathrm{~s}$, followed by 35 cycles with a denaturation step of $94{ }^{\circ} \mathrm{C}$ for $20 \mathrm{~s}$, an annealing step of $59^{\circ} \mathrm{C}$ for $30 \mathrm{~s}$, an extension step of $68{ }^{\circ} \mathrm{C}$ for $60 \mathrm{~s}$ and a final extension of $68{ }^{\circ} \mathrm{C}$ for five minutes. The PCR protocol for the small fragment $18 \mathrm{~S}$ rRNA gene was as follows: an initial denaturation step of $94{ }^{\circ} \mathrm{C}$ for $30 \mathrm{~s}$, followed by 35 cycles with a denaturation step of $94{ }^{\circ} \mathrm{C}$ for $20 \mathrm{~s}$, an annealing step of $59^{\circ} \mathrm{C}$ for $30 \mathrm{~s}$, an extension step of $68^{\circ} \mathrm{C}$ for $60 \mathrm{~s}$ and a final extension of $68{ }^{\circ} \mathrm{C}$ for five minutes. All PCR reactions were performed on a PTC-200 Thermal Cycler (MJ Research, Quebec, Canada).

Successful amplification resulted with products of $333 \mathrm{bp}$ and $658 \mathrm{bp}$ for the 18S rRNA gene and COI, respectively. In order to assess whether the targeted gene was amplified, a $5 \mu \mathrm{L}$ aliquot of PCR product was electrophoresed on a $1.5 \%$ agarose gel and visualized. PCR products were then purified using the Zymo Clean \& Concentrator Kit (Irvine, CA), prior to bi-directional sequencing with the $3730 \mathrm{XL}$ DNA Analyzer (Life Technologies, Grand Island, NY) using the Big Dye Terminator 3.1 Cycle Sequencing Kit (Life Technologies, Grand Island, NY) at New England Biolabs (Ipswich, Massachusetts).

\section{Data analysis}

All trace files were edited individually to remove primers and low-quality ends, and inspected for ambiguous base-calls. Complementary strands of 
COI (658 bp) and of 18S rRNA gene (333bp) sequences were edited and aligned manually using MEGA v. 6.1 (Tamura et al. 2013) and checked for possible occurrence of indels (insertions and deletions). In addition, COI sequences were translated into amino acid sequences to check for nuclear mitochondrial pseudogenes (numts) and inspected for the presence of stop codons or unusual amino acid sequence patterns present in the alignment. All sequences (COI and 18S) were then submitted to BLASTN search at the National Centre for Biotechnology Information (NCBI) and, in the case of COI sequences, also to homology searches in the BOLD Identification System (BOLD-IDS) (Ratnasingham and Hebert 2007) to confirm the target taxa. For each submitted COI sequence, the maximal levels of identity, expressed in percentages in both public databases, were compared in order to ensure that endosymbiont bacteria and other potential contaminants had not been amplified in error.

MUSCLE (Edgar 2004) implemented in MEGA (Thompson et al. 1994) was used to carry out the multiple alignments for the COI and 18S rRNA gene sequences. We used the neighbor-joining (NJ) and maximum likelihood (ML) method with best fit model $\mathrm{HKY}+\mathrm{G}+\mathrm{I}$ for $\mathrm{COI}$ and $\mathrm{JC}+\mathrm{G}$ for $18 \mathrm{~S}$ rRNA gene, to construct both phylograms for COI and $18 \mathrm{~S}$ rRNA gene sequences obtained in this study and mined from GenBank. The Kimura 2-parameter model (K2P) was used to allow comparisons with other studies where K2P is the standard genetic distance used. The bootstrap support for the nodes was determined using 1000 iterations. In addition, we also used amino acid COI sequences to construct a NJ phylogram (not shown), using Jones-TaylorThornton (JTT) model (Jones et al. 1992) with node support consisting of 1000 non-parametric bootstrap replicates (Felsenstein 1985). Average pairwise genetic distances were calculated within and among major clusters in the ML tree using K2P substitution model that enables direct comparison with genetic distances from other studies.

\section{Results}

\section{Morphology-based identification of specimens}

This study generated new COI sequences from 16 specimens. All specimens possessed pallets and were morphologically identified to species level. The 16 specimens were: three Nototeredo norvagica (Spengler, 1792), three Psiloteredo megotara (two collected from test panels exposed in Norway and one collected from a test panel in Sweden), six JTMD Psiloteredo sp., and four JTMD Teredora princesae. Partial 18S rRNA gene sequences were obtained from 26 specimens. Of these, 25 specimens were identified morphologically to species level and one specimen to genus level. Of the 26 specimens, the following species were identified and sequenced for the 18S rRNA gene in this study: one Bankia bipennata specimen from JTMD; one Bankia carinata from JTMD, seven Psiloteredo sp. from JTMD; eight $P$. megotara (five from Swedish test panels and three from Norwegian test panels), one Teredora sp.; five Teredora princesae from JTMD, and three Teredothyra smithi from JTMD (Table 1).

\section{Delineation of species and phylogenetic reconstruction using COI-5P and partial $18 S$ rRNA sequences}

To the COI sequences obtained in the present study, we added 14 sequences of teredinids published by Borges et al. (2012) and a GenBank sequence of the bivalve mollusk (scallop) Pecten jacobaeus (Linnaeus, 1758) to use as outgroup in our analysis. The final alignment comprised 32 sequences of seven morphospecies (Table 1) and 95\% of our sequences were longer than $600 \mathrm{bp}$. The sequences aligned unambiguously and were free from indels (insertions and deletions) and the translation into amino acids showed no frame shift mutations, stop codons, or unusually divergent amino acid profiles in the alignment. A search of homologies in GenBank and BOLD IDs for specimens morphologically identified as Nototeredo norvagica returned $99-100 \%$ similarity with $N$. norvagica specimens from the studies by Borges et al. (2012) and Weigelt et al. (2016). Novel sequences were produced for Psiloteredo megotara from Sweden and Norway, Psiloteredo sp. JTMD and Teredora princesae JTMD. The nearest matches for these species were with Lyrodus pedicellatus (Quatrefages, 1849) (82\%), N. norvagica (81\%) and Teredo navalis $(80 \%)$. These results rule out the possibility of contamination by, for instance, endosymbiont bacteria.

The NJ and ML of COI sequences showed identical topologies and were able to sort all morpho-species in our dataset; herein, we show only the ML phylogram (Figure 2). Specimens of the morphospecies Psiloteredo megotara formed two monophyletic clusters, one including the specimens from Norway and Sweden, and the other including JTMD specimens (shown in Figure 2 as Psiloteredo sp.). The average K2P distance between the two clusters was $12.8 \%$, the minimum inter-specific distance found in this study. The maximum inter-specific distance $(34.8 \%)$ was found between $P$. megotara and Teredothyra dominicensis. The intra- specific 


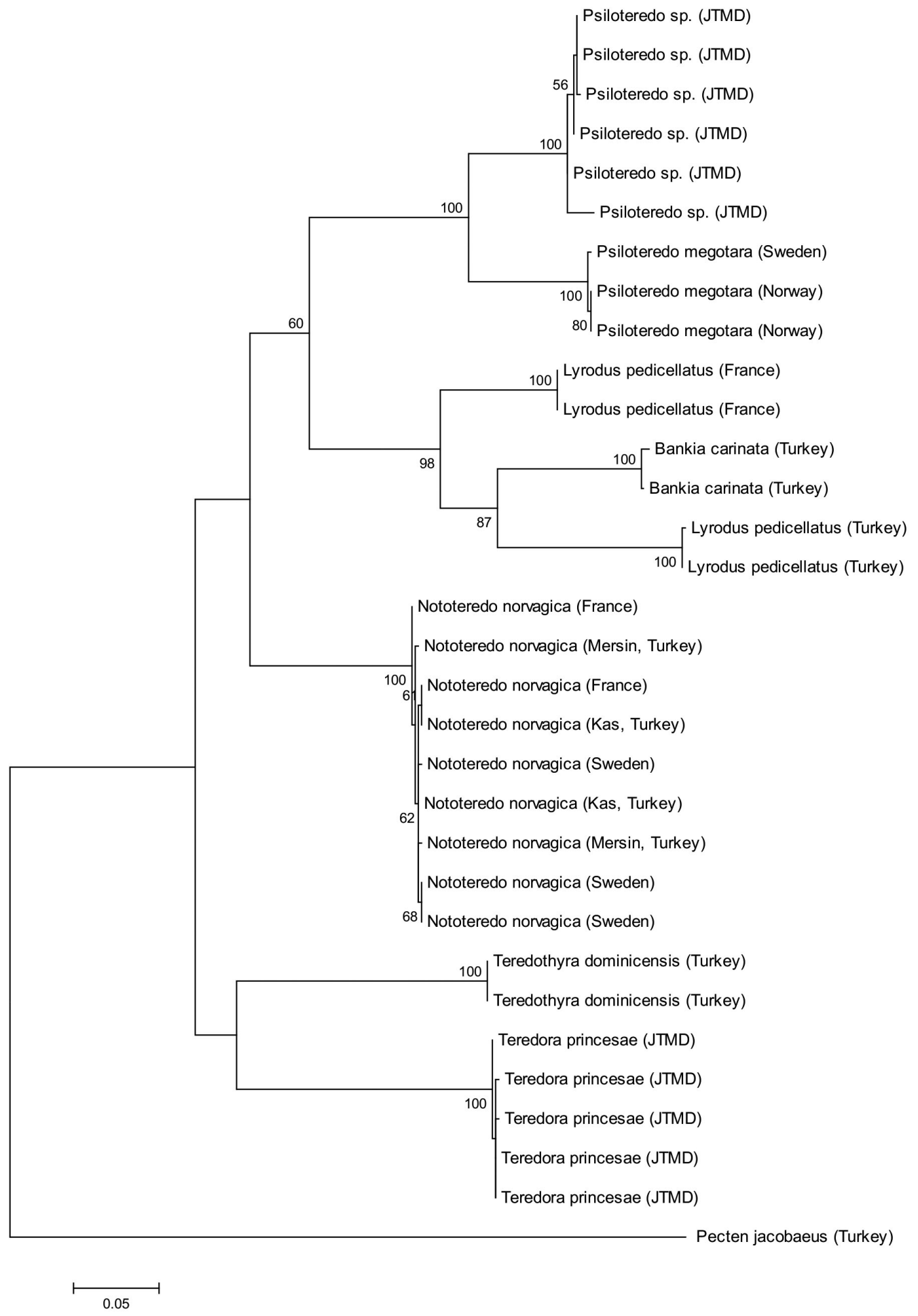

Figure 2. Maximum-likelihood phylogram of partial sequences of the cytochrome $c$ subunit I gene. Numbers associated with nodes represent bootstrap values greater than 50 . Scale bar indicates 0.05 substitutions per site. 
distance was lower than $2 \%$ in all groups varying from a maximum of $0.9 \%$ in Psiloteredo sp. JTMD and a minimum of $0 \%$ in $T$. dominicensis and Lyrodus pedicellatus Mediterranean form (Supplementary material Table S1).

In addition to the COI sequences, we obtained 26 partial 18S rRNA gene sequences. To these, we added 18 sequences available from GenBank (Giribet and Wheeler 2002; Taylor et al. 2007; Distel et al. 2011; Borges et al. 2012) including the bivalve (piddock) Pholas dactylus (Linnaeus, 1758), which was used as the out-group. Forty-four sequences of 11 morphospecies were analyzed. A search of homologies in GenBank (BLAST) showed low nearest matches $(\leq 98 \%)$ for seven of the species sequenced in this study. The ML phylogram (Figure 3) shows clearly defined and well supported clusters for some of the morphospecies analyzed. However, L. pedicellatus, both Atlantic and Mediterranean forms, and Bankia carinata from the Mediterranean cluster together. The latter species can be distinguished from the former two by a K2P distance of $0.3 \%$. Similarly, Teredora princesae and Bankia carinata JTMD cluster together, with a $0 \% \mathrm{~K} 2 \mathrm{P}$ distance. Psiloteredo megotara from Norway and Sweden form a group with Psiloteredo sp. JTMD, the K2P distance between species in this group is $0 \%$. The genetic pairwise distance was lower in the 18S rRNA gene than in COI (Table S2). The within group genetic distance was $0 \%$ for all groups with more than one specimen. The main distance between the groups in the ML tree varied from a minimum of $0 \%$ in P. megotara and Psiloteredo sp. JTMD and a maximum of $5.3 \%$ in B. carinata JTMD and $B$. carinata from Netherlands Antilles and Tobago.

\section{Discussion}

The application of molecular techniques to taxonomic questions in the Teredinidae is especially useful due to intraspecific and interspecific morphological variation in their calcareous structures (Figure 1). The COI sequences obtained from two of the five JTMD morpho-species, combined with extra COI sequences from GenBank confirms previous observations by Borges et al. (2012) and Shipway et al. (2014) of the high potential of this marker for species delineation in the Teredinidae, as it has in other taxonomic groups (Sá-Pinto et al. 2008; Raupach et al. 2010, 2015). Nuclear 18S rRNA gene sequences from all five broadcasting species present in JTMD (Bankia carinata, Bankia bipennata, Psiloteredo sp., Teredora princesae, Teredothyra smithi) show this gene to evolve slowly in the Teredinidae compared to COI; it is therefore less useful as a tool for species delineation.

\section{A cryptic Psiloteredo species}

The ML phylogram of the partial 18S rRNA sequences was not able to distinguish between JTMD and Scandinavian Psiloteredo, and yet the 12.8\% K2P distance in the COI sequences clearly delineates specimens morphologically identified as Psiloteredo megotara from Scandinavia and Psiloteredo sp. JTMD into two distinct groups. The within group K2P distances in Psiloteredo sp. JTMD (0.9\%) and $P$. megotara from Scandinavia $(0.3 \%)$ are within the expected range of variation found within species. Therefore, our genetic analysis indicates that North Pacific Psiloteredo sp. and North Atlantic Psiloteredo megotara are a cryptic species pair.

Psiloteredo megotara was described by Hanley in Forbes and Hanley (1848) from England. This coldwater species has been reported mainly from the eastern North Atlantic, occurring infrequently in test panels and maritime structures (Norman 1977; Appelqvist et al. 2015), except in Trondheim Fjord, Norway, where it is the most common shipworm (Santhakumaran and Sneli 1978; Santhakumaran and Sneli 1984; Borges et al. 2014). P. megotara has been reported occasionally along the Atlantic coast of North America (Berg et al. 1987), with a more consistent presence in offshore waters (Brown 1953; Wallour 1960). More recently, this species was reported in sunken wood from depths of 250-500 m in the offshore waters of the northeastern coast of Honshu, Japan (Okutani et al. 2009). Pallets from the study by Okutani et al. (2009), generously provided by T. Haga (National Museum of Nature and Science, Tsukuba, Japan), were compared to pallets of Psiloteredo sp. JTMD and pallets of P. megotara from Scandinavia, with the conclusion that the pallet construction and morphological forms of all three were so similar as to be of the same morphospecies. Therefore, it is likely that the P. megotara specimens reported by Okutani et al. 2009 from northern Japan, where JTMD originated, is the same species as Psiloteredo sp. JTMD. In addition to this $P$. megotara was reported by Nishimoto et al. 2015 in wood test logs placed in Tanabe Bay, Japan. The lack of divergence in partial 18S rRNA gene sequences (Table S2) and identical pallet architecture between Northwest Pacific (NWP) Psiloteredo sp. and Psiloteredo megotara (North Atlantic) are evidence of a close phylogenetic relationship with a geologically recent divergence between the two species. The taxonomic identity and possible distribution of Psiloteredo in Japan is to be addressed in a forthcoming publication. 


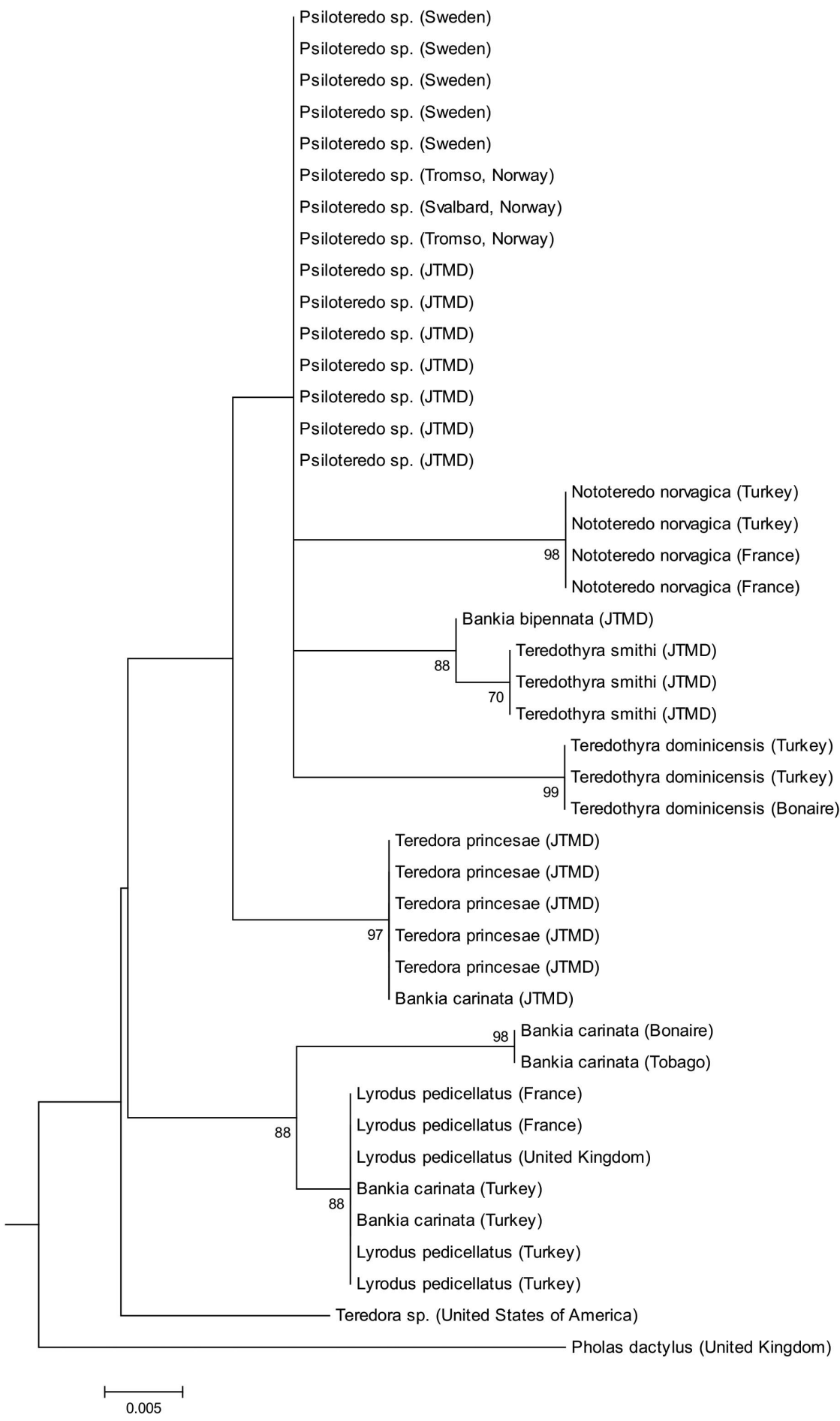

Figure 3. Maximum-likelihood phylogram of partial 18S rRNA gene sequences. Only bootstrap values greater than 50 are shown associated with the nodes. The scale bar indicates 0.005 substitutions per site. 
18S rRNA gene analysis and the position of Bankia species in the ML phylogram

The 18S rRNA phylogeny produced in this study shows several incongruities. The most difficult one to resolve is presented by the genus Bankia. Bankia carinata, a cosmopolitan species found throughout warm marine coastal waters (Turner 1971; Encyclopedia of Life http://www.eol.org, accessed 20 November 2016) forms separate clades depending on the geographic source of the specimens. European Bankia carinata groups with Lyrodus, a relationship seen in other phylogenetic analyses (Distel et al. 2011; Borges et al. 2012). Molecular analysis of the $18 \mathrm{~S}$ rRNA gene fragment failed to separate JTMD $B$. carinata from Teredora princesae, a very surprising result, as is the grouping of Bankia bipennata with Teredothyra smithi. Species within the genus Bankia all have segmented pallets (Turner 1966, 1971), a feature that sets them morphologically apart. These nuclear sequences show this group as polyphyletic and scattered amongst other shipworm genera and are another indication that other molecular markers are needed for a correct phylogenetic analysis of the Teredinidae.

The use of additional nuclear markers in conjunction with COI-5P sequences has been favored by several studies (Raupach et al. 2010; Borges et al. 2012; Carstens et al. 2013; Shipway et al. 2014) in order to avoid the limitations and pitfalls of using single COI-5P sequences, such as the co-amplification of pseudogenes (Song et al. 2008). More specimens and species from a variety of geographic regions, and sequencing of multiple markers with higher resolution such as microsatellite markers and single nucleotide polymorphisms (SNPs), are needed to distinguish the phylogenetic relationships within this family.

\section{Tsunamis as a mode of dispersal for wood borers}

The discovery of live shipworms in wood rafted across more than $7000 \mathrm{~km}$ of ocean demonstrates that tsunamis are a potential vector for species transport from east to west. Such rafting may lead to the establishment of NWP species in the Northeast Pacific (NEP) and/or islands (including Hawaii) of the north Pacific. The similarities in ecological conditions between northern Japanese waters and the NEP (Tsunoda 1979; Agatsuma et al. 2014; Hofmann et al. 2014; Riche et al. 2014) suggest that Psiloteredo $\mathrm{sp}$. has the potential to become an established species in the NEP. While the warm water shipworms (Bankia bipennata, Bankia carinata, and Teredothyra smithi) in JTMD are unlikely to establish populations along the colder shores of the NEP, these species were also found in wood JTMD arriving on the Hawaiian coast, where conditions are more ecologically suitable for their establishment. This study supports the hypothesis that tsunamis may have a significant influence on the movement of species between ocean provinces in geologic time.

\section{Summary}

Woody debris from the 2011 Japanese tsunami rafted living shipworms to the Northeastern Pacific and Hawaiian shores. Phylogenetic analysis of COI and $18 \mathrm{~S}$ rRNA sequences obtained from five species of shipworm in this debris was performed. A genetic distance of $12.8 \%$ in the COI barcode fragment was calculated between the species Psiloteredo megotara and the morphologically similar JTMD species Psiloteredo sp. and no difference was found in the 18S rRNA fragment of these two species. In addition, COI and 18S rRNA gene sequences of Teredora princesae were obtained, along with nuclear sequences from Bankia carinata, Bankia bipennata, and Teredothyra smithi. The 18S rRNA analysis produced incongruent results, with Bankia species scattered amongst different taxonomic groups with widely different morphology, indicating a need for multiple genetic markers to produce a robust phylogeny of the Teredinidae. Although tsunamis of the magnitude of the one in 2011 occur infrequently in geologic time, this study shows that they have the potential to transport species to geographic areas isolated by large distances.

\section{Acknowledgements}

Many people contributed their time, expertise, and tools to this research. We thank John Chapman, Steve Rumrill, Christin Appelqvist, Takuma Haga, Atsushi Nishimoto, Regi Kawamoto, Adam Baldinger, Russ Lewis, Nikolai Maximenko, Neil Holcomb, Dave and Diane Bilderback, Craig Young, the Oregon Islands National Wildlife Refuge, the Washington Department of Fish and Wildlife, Kauai Surfrider Foundation, Stephen Holland, Paul Gabrielson, James Treneman and Dana Garves. Funding for JTMD research was generously provided by Oregon Sea Grant, the National Science Foundation, and the Japanese Ministry of the Environment (MoE) through the North Pacific Marine Science Organization (PICES).

\section{References}

Agatsuma Y, Endo H, Yoshida S, Ikemori C, Takeuchi Y, Fujishima H, Nakajima K, Mitsuhiro S, Nobuyuki K, Imai H, Yamamoto N, Kanahama H, Matsubara T, Takahashi S, Isogai T, Taniguchi K (2014) Enhancement of Saccharina kelp production by nutrient supply in the Sea of Japan off southwestern Hokkaido, Japan. Journal of Applied Phycology 26: 1845-1852, https://doi.org/10.1007/s10811-013-0196-z

Appelqvist C, Havenhand JN, Toth GB (2015) Distribution and abundance of teredinid recruits along the Swedish coast - are shipworms invading the Baltic Sea? Journal of the Marine Biological Association of the United Kingdom 95: 783-790, https://doi.org/10.1017/S0025315414001830 
Berg Jr CJ, Early JA, Butman B, Turner RD (1987) Seasonal recruitment of marine invertebrates to hard substrates on Georges Bank and the eastern continental shelf of the United States. The Nautilus 101: 19-24

Blaxter ML, De Ley P, Garey JR, Liu LX, Scheldeman P, Vierstraete A, Vanfleteren JR, Mackey LY, Dorris M, Frisse LM, Vida JT (1998) A molecular evolutionary framework for the phylum Nematoda. Nature 392(6671): 71-75, https://doi.org/10.1038/32160

Borges LMS (2015) The internal structure of the pallets of Nototeredo norvagica and Psiloteredo megotara (Bivalvia: Teredinidae): implications for subfamilial allocations. Zoomorphology 135: 33-41, https://doi.org/10.1007/s00435-015-0277-4

Borges LM, Merckelbach LM, Sampaio Í, Cragg SM (2014) Diversity, environmental requirements, and biogeography of bivalve wood-borers (Teredinidae) in European coastal waters. Frontiers in Zoology 11: 13, https://doi.org/10.1186/1742-9994-11-13

Borges LM, Sivrikaya H, Le Roux A, Shipway JR, Cragg SM, Costa FO (2012) Investigating the taxonomy and systematics of marine wood borers (Bivalvia: Teredinidae) combining evidence from morphology, DNA barcodes and nuclear locus sequences. Invertebrate Systematics 26: 572-582, https://doi.org/10.1071/IS12028

Brown DJ (1953) Sixth Progress Report on Marine Borer Activity in Test Boards Operated during 1952. WF Clapp Laboratories, Duxbury, Mass, $200 \mathrm{pp}$

Calloway CB, Turner RD (1987) Species pairs in the Teredinidae. International Research Group on Wood Preservation 1987: 1-2

Calloway CB, Turner RD (1988) Brooding in the Teredinidae (Mollusca: Bivalvia). In: Thompson MF, Sarojiani R, Nagabhushanam R (eds), Marine Biodeterioration: Advanced Techniques Applicable to the Indian Ocean. AA Balkema, Rotterdam, pp 215-226

Carlton JT (1987) Patterns of transoceanic marine biological invasions in the Pacific Ocean. Bulletin of Marine Science 41: 452-465

Carlton JT (1999) Molluscan invasions in marine and estuarine communities. Malacologia 41: 439-454

Carlton JT (2009) Deep invasion ecology and the assembly of communities in historical time. In: Rilov G, Crooks JA (eds), Biological Invasions in Marine Ecosystems. Springer-Verlag, Berlin, Heidelberg, pp 13-56, https://doi.org/10.1007/978-3-540-792 36-9_2

Carlton JT, Chapman JWC, Geller JB, Miller JA, Carlton DA, McCuller MI, Treneman N, Steves BP, Ruiz GM (2017) Tsunami-driven rafting: Transoceanic species dispersal and implications for marine biogeography. Science 357: 1402-1406, https://doi.org/10.1126/science.aao1498

Carlton JT, Eldredge LG (2009) Marine bioinvasions of Hawaii. Bernice P. Bishop Museum/Bishop Museum Press, 202 pp

Carstens BC, Pelletier TA, Reid NM, Satler JD (2013) How to fail at species delimitation. Molecular Ecology 22: 4369-4383, https://doi.org/10.1111/mec.12413

Distel DL, Goodell B, Nicholas DD, Schultz TP (2003) The biology of marine wood boring bivalves and their bacterial endosymbionts. In: Schultz T, Goodell B, Nicholas D (eds), Current Knowledge of Wood Deterioration Mechanisms and its Impact on Biotechnology and Wood Preservation. Symposium at the 221st National Meeting of the American Chemical Society, San Diego, California, USA, 1-5 April 2001. American Chemical Society, pp 253-271, https://doi.org/10.1021/bk-2003-0845.ch014

Distel DL, Amin M, Burgoyne A, Linton E, Mamangkey G, Morrill W, Nove J, Wood N, Yang J (2011) Molecular phylogeny of Pholadoidea Lamarck, 1809 supports a single origin for xylotrophy (wood feeding) and xylotrophic bacterial endosymbiosis in Bivalvia. Molecular Phylogenetics 61: 245-254, https://doi.org/ 10.1016/j.ympev.2011.05.019

Edgar RC (2004) MUSCLE: a multiple sequence alignment method with reduced time and space complexity. BMC Bioinformatics 5: 113, https://doi.org/10.1186/1471-2105-5-113

Edmondson CH (1962) Teredinidae, Ocean Travelers. Occasional Papers of the Bernice P. Bishop Museum 23: 45-59
Felsenstein J (1985) Confidence limits on phylogenies: an approach using the bootstrap. Evolution 39: 783-791, https://doi.org/10.1111/ j.1558-5646.1985.tb00420.x

Folmer O, Black M, Hoeh W, Flutz R, Vrijenhoek R (1994) DNA primers for amplification of mitochondrial cytochrome $c$ oxidase subunit I from diverse metazoan invertebrates. Molecular Marine Biology and Biotechnology 3: 294-299

Forbes E, Hanley S (1848) A History of the British Mollusca, Vol. 1. London, John Van Voorst, $486 \mathrm{pp}$

Giribet G, Wheeler W (2002) On bivalve phylogeny: a high-level analysis of the Bivalvia (Mollusca) based on combined morphology and DNA sequence data. Invertebrate Biology 121: 271-324, https://doi.org/10.1111/j.1744-7410.2002.tb00132.x

Haga T (2017) Teredinidae. In: Okutani T (ed), Marine Mollusks in Japan. The Second Edition. Tokai University Press, Kiratsuka, pp 610-611, 1273-1276

Hofmann GE, Evans TG, Kelly MW, Padilla-Gamiño JL, Blanchette CA, Washburn L, Chan F, McManus MA, Menge BA, Gaylord B, Hill TM (2014) Exploring local adaptation and the ocean acidification seascape-studies in the California Current Large Marine Ecosystem. Biogeosciences 11: 1053-1064, https://oi. org/10.5194/bg-11-1053-2014

Jones DT, Taylor WR, Thornton JM (1992) The rapid generation of mutation data matrices from protein sequences. Computer Applications in the Biosciences: CABIOS 8: 275-282, https://doi. org/10.1093/bioinformatics/8.3.275

Lozouet P, Plaziat JC (2008) Mangrove Environments and Molluscs. Conchbooks, Hackenheim, $155 \mathrm{pp}$

MacIntosh H (2012) Lyrodus turnerae, a new teredinid from eastern Australia and the Coral Sea (Bivalvia: Teredinidae). Molluscan Research 31: 36-42

MacIntosh H, De Nys R, Whalan S (2012) Shipworms as a model for competition and coexistence in specialized habitats. Marine Ecology Progress Series 461: 95-105, https://doi.org/10.3354/meps09823

MacIntosh H, de Nys R, Whalan S (2014) Contrasting life histories in shipworms: Growth, reproductive development and fecundity. Journal of Experimental Marine Biology and Ecology 459: 8086, https://doi.org/10.1016/j.jembe.2014.05.015

Maximenko N, MacFadyen A, Kamachi M (2015) Modeling the drift of marine debris generated by the 2011 tsunami in Japan. PICES Press 23, 5 pp

Meeker ND, Hutchinson SA, Ho L, Trede NS (2007) Method for isolation of PCR-ready genomic DNA from zebrafish tissues. Biotechniques 43: 610-614, https://doi.org/10.2144/000112619

Morgulis M, Coulouris G, Rayselis Y, Madden TL, Agarwala R, Schäffer AA (2008) Database indexing for production MegaBLAST searches. Bioinformatics 24: 17157-17164, https://doi.org/10.1093/bioinformatics/btn554

Nelson DL (2016) The ravages of Teredo: the rise and fall of shipworm in US history, 1860-1940. Environmental History 21:100-124, https://doi.org/10.1093/envhis/emv118

Norman E (1977) The geographical distribution and the growth of the wood-boring molluscs Teredo navalis L., Psiloteredo megotara (Hanley) and Xylophaga dorsalis (Turton) on the Swedish west coast. Ophelia 16: 233-250, https://doi.org/10.1080/ 00785326.1977.10425473

Okutani T, Saito H, Haga T (2009) Shelf to bathyal bivalve and scaphopod mollusks collected by the R/V Wakataka-maru from off Pacific coast of northern Japan during the years 2005-2006. In: Fujita $\mathrm{T}$ (ed), National Museum of Nature and Science Monographs 39, pp 193-223

Ratnasingham S, Hebert PD (2007) BOLD: The Barcode of Life Data System (http://www.barcodinglife.org). Molecular Ecology Notes 7: 355-364, https://doi.org/10.1111/j.1471-8286.2007.01678.x

Raupach MJ, Astrin JJ, Hannig K, Peters MK, Stoeckle MY, Wägele JW (2010) Molecular species identification of Central European ground beetles (Coleoptera: Carabidae) using nuclear rDNA expansion segments and DNA barcodes. Frontiers in Zoology 7 : 26, https://doi.org/10.1186/1742-9994-7-26 
Raupach MJ, Barco A, Steinke D, Beermann J, Laakmann S, Mohrbeck I, Neumann H, Kihara TC, Pointner K, Radulovici A, Segelken-Voigt A (2015) The application of DNA barcodes for the identification of marine crustaceans from the North Sea and adjacent regions. PLoS ONE 10: e0139421, https://doi.org/10.1371/ journal.pone. 0139421

Rayner SM (1983) Distribution of teredinids (Mollusca: Teredinidae) in Papua New Guinea. Records of the Australian Museum 35: 61-76, https://doi.org/10.3853/j.0067-1975.35.1983.302

Riche O, Johannessen SC, Macdonald RW (2014) Why timing matters in a coastal sea: trends, variability and tipping points in the Strait of Georgia, Canada. Journal of Marine Systems 131: 36-53, https://doi.org/10.1016/j.jmarsys.2013.11.003

Rowan R, Powers DA (1992) Ribosomal RNA sequences and the diversity of symbiotic dinoflagellates (zooxanthellae). Proceedings of the National Academy of Sciences 89: 3639-3643, https://doi.org/10.1073/pnas.89.8.3639

Santhakumaran LN, Sneli JA (1978) Natural resistance of different species of timber to marine borer attack in the Trondheimsfjord (Western Norway). International Research Group on Wood Preservations IRG/WP/435

Santhakumaran LN, Sneli JA (1984) Studies on the marine fouling and wood-boring organisms of the Trondheimsfjord (Western Norway). Gunneria 48: 1-30

Sá-Pinto AL, Branco M, Sayanda D, Alexandrino P (2008) Patterns of colonization, evolution and gene flow in species of the genus Patella in the Macaronesian Islands. Molecular Ecology 17: 519-532, https://doi.org/10.1111/j.1365-294X.2007.03563.x

Shipway JR, Borges LM, Müller J, Cragg SM (2014) The broadcast spawning Caribbean shipworm, Teredothyra dominicensis (Bivalvia, Teredinidae), has invaded and become established in the eastern Mediterranean Sea. Biological Invasions: 16: 20372048, https://doi.org/10.1007/s10530-014-0646-9

Shipway JR, O'Connor R, Stein D, Cragg SM, Korshunova T, Martynov A, Haga T, Distel DL (2016) Zachsia zenkewitschi (Teredinidae), a rare and unusual seagrass boring bivalve revisited and redescribed. PLOS ONE 11: e0155269, https://doi.org/10.1371/ journal.pone. 0155269

Song H, Buhay JE, Whiting MF, Crandall KA (2008) Many species in one: DNA barcoding overestimates the number of species when nuclear mitochondrial pseudogenes are coamplified. Proceedings of the National Academy of Science 105: 1348613491, https://doi.org/10.1073/pnas.0803076105

Tamura K, Stecher G, Peterson D, Filipski A, Kumar S (2013) MEGA6: molecular evolutionary genetics analysis version 6.0. Molecular Biology and Evolution 30: 2725-2729, https://doi.org/ 10.1093/molbev/mst197

Taylor JD, Williams ST, Glover EA, Dyal P (2007) A molecular phylogeny of heterodont bivalves (Mollusca: Bivalvia: Heterodonta): new analyses of $18 \mathrm{~S}$ and $28 \mathrm{~S}$ rRNA genes. Zoologica Scripta 36: 587-606, https://doi.org/10.1111/j.1463-6409.2007.00299.x
Thiel M, Haye PA (2006) The ecology of rafting in the marine environment. III. Biogeographical and evolutionary consequences. In: Gibson RN, Atkinson RJA, Gordon JDM (eds), Oceanography and Marine Biology: An Annual Review. Volume 44, pp 323-429, https://doi.org/10.1201/9781420006391.ch7

Thompson JD, Higgins DG, Gibson TJ (1994) CLUSTAL W: improving the sensitivity of progressive multiple sequence alignment through sequence weighting, position-specific gap penalties and weight matrix choice. Nucleic Acids Research 22: 4673-4680, https://doi.org/10.1093/nar/22.22.4673

Treneman NC, Carlton JT, Borges LMS, Shipway JR, Raupach MJ, Altermark B (2018) Species diversity and abundance of shipworms (Mollusca: Bivalvia: Teredinidae) in woody marine debris generated by the Great East Japan Earthquake and Tsunami of 2011. Aquatic Invasions 13: 87-100, https://doi.org/ 10.3391/ai.2018.13.1.07

Tsunoda K (1979) Ecological studies of shipworm attack on wood in the sea water log storage site. Wood Research: Bulletin of the Wood Research Institute, Kyoto University 65: 11-53

Turner RD (1966) A Survey and Illustrated Catalogue of the Teredinidae (Mollusca: Bivalvia). Museum of Comparative Zoology, Cambridge, Mass, $265 \mathrm{pp}$

Turner RD (1971) Identification of marine wood-boring molluscs. In: Jones EBG, Eltringham SK (eds), Marine Borers, Fungi, and Fouling Organisms of Wood. Organisation for Economic Cooperation and Development, Paris, pp 17-64

Turner RD, Johnson AC (1971) Biology of marine wood-boring molluscs. In: Jones EBG, Eltringham SK (eds), Marine Borers, Fungi, and Fouling Organisms of Wood. Organisation for Economic Co-operation and Development, Paris, pp 259-301

Voight JR (2015) Xylotrophic bivalves: aspects of their biology and the impacts of humans. Journal of Molluscan Studies 81: 175186, https://doi.org/10.1093/mollus/eyv008

Wallour DB (1960) Thirteenth Report on Marine Borer Activity in Test Boards Operated during 1959. William F. Clapp Laboratories, Duxbury, Mass, $59 \mathrm{pp}$

Weigelt R, Lippert H, Borges LM, Appelqvist C, Karsten U, Bastrop R (2016) First time DNA barcoding of the common shipworm Teredo navalis Linnaeus 1758 (Mollusca: Bivalvia: Teredinidae): Molecular-taxonomic investigation and identification of a widespread wood-borer. Journal of Experimental Marine Biology and Ecology 475: 154-162, https://doi.org/10.1016/j.jembe.2015.11.008

Zhang Z, Schwartz S, Wagner L, Miller W (2000) A greedy algorithm for aligning DNA sequences. Journal of Computational Biology 7: 203-214, https://doi.org/10.1089/10665270050081478

\section{Supplementary material}

The following supplementary material is available for this article:

Table S1. Pairwise K2P distance for COI-5P sequences of teredinid groups.

Table S2. Pairwise distance K2P for 18S rRNA gene sequences of teredinid groups.

This material is available as part of online article from:

http://www.aquaticinvasions.net/2018/Supplements/AI_2018_JTMD_Treneman_etal2_SupplementaryTables.xlsx 